\title{
Crystal Structure, Spectral Characterization and Biologically Studies of Mononuclear Transition Metal Complexes Derived from New $\mathrm{N}_{2} \mathrm{O}_{2}$ Type Ligand
}

Samina K Tadavi ${ }^{1}$, Jamatsing D Rajput ${ }^{1}$, Suresh D Bagul ${ }^{1}$, Jaiprakash N Sangshetti ${ }^{3}$, Amar A Hosamani ${ }^{2}$ and Ratnamala S Bendre ${ }^{1 *}$

${ }^{1}$ School of Chemical Sciences, North Maharashtra Jalgaon, Maharashtra, India

${ }^{2}$ Solid State and Structural Chemistry Unit, Indian Institute of Science, Bangalore, Karnataka, India

${ }^{3}$ YB Chavan College of Pharmacy, Dr. Rafiq Zakaria Campus, Aurangabad, Maharashtra, India

\begin{abstract}
The new mononuclear metal complexes viz $\mathrm{Mn}(\mathrm{III}), \mathrm{Co}(\mathrm{II}), \mathrm{Ni}(\mathrm{II})$ and $\mathrm{Cu}(\mathrm{II})$ have been synthesized by using tetradentate $\mathrm{N} 2 \mathrm{O} 2$ donor symmetric schiff base 6,6'-((1E,1'E)-(1,2-phenylenebis(azanylylidene))bis(methanylylidene)) bis(5-isopropyl-2-methylphenol) $\mathrm{HL}$ and employing with corresponding metal chloride or acetate salts. After successful synthesis of compounds were thoroughly characterized by Elemental analysis, FT-IR, Uv-visible, NMR spectroscopy, LC-MS spectrometry, SEM analysis, Magnetic susceptibility measurement, Molar conductance, ESR spectroscopy. $\mathrm{X}$-ray single crystal structure of $\mathrm{HL}$ schiff base has been determined. The synthesized compounds have been screened for their antimicrobial and antioxidant activities, which show significant results.
\end{abstract}

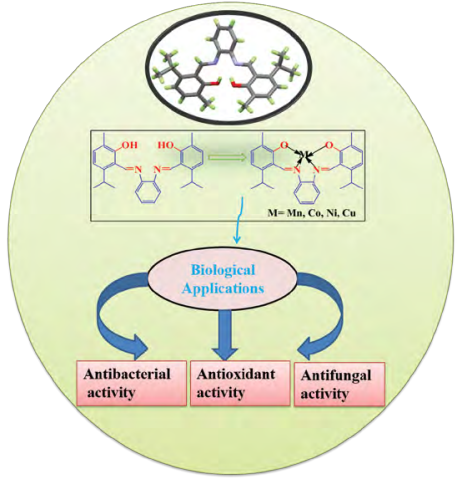

Keywords: Schiff base; Mononuclear transition metal complexes; ESR; Antimicrobial activity; Antioxidant activity

\section{Introduction}

Schiff bases $(\mathrm{RHC}=\mathrm{NR})$ are a class of organic compounds typically formed by condensation of a primary amine and an aldehyde and they are considered as privilege ligand [1,2]. Schiff base ligands with $\mathrm{N}_{2} \mathrm{O}_{2}$ donor atoms are well known to coordinate with a variety of metal ions. They have attracted much interest in recent years, due to ease of synthesis, their stability under a variety of oxidative and reductive conditions and their structural versatility associated with various applications. These compounds have various applications in industries as dyes, drug synthesis [3] bioinorganic chemistry [4] electrochemistry [5] dioxygen uptake and catalysis [6-10]. Tetra-dentate $\mathrm{N}_{2} \mathrm{O}_{2}$ donors schiff bases derived from o-phenylenediamine and salicyaldehyde have been widely studied in solid state. They have been studied for a variety of applications including biological, clinical and analytical. The previous work has shown that some drugs showed increased activity when administered as metal chelates rather than as organic compounds [11-13]. A search through literature reveals that no work has been done on the transition metal complexes of the symmetrical schiff base derived from o-phenylenediamine and 2-hydroxy-6isopropyl-3-methyl benzaldehyde. In this paper, we report synthesis of a new type of tetradentate Schiff base ligand formed by the simple condensation of o-phenylenediamine with 2-hydroxy-6-isopropyl3-methyl benzaldehyde and its $\mathrm{Mn}$ (III), $\mathrm{Co}(\mathrm{II}), \mathrm{Ni}(\mathrm{II})$ and $\mathrm{Cu}(\mathrm{II})$ mononuclear complexes. The prepared ligand and complexes were characterized using Elemental analysis, FT-IR, UV-visible, NMR, LC-
MS, ESR and crystal structure and further screened for antimicrobial and antioxidant activity.

\section{Experimental}

All the solvents and chemicals were of commercial reagent grade and used as received without further purification. FT-IR spectra were recorded as $\mathrm{KBr}$ pellets on a SHIMADZU FT-IR- 8400 spectrometer from range 4000 to $400 \mathrm{~cm}^{-1}$. The electronic spectra were recorded in DMF solutions on the UV 2400 series spectrophotometer. ${ }^{1} \mathrm{H}$ and ${ }^{13} \mathrm{C}$ NMR spectra were precise with a BRUKER AVANCE III $(400 \mathrm{MHz})$ spectrometer and proton chemical shifts are recorded in ppm relative to tetramethylsilane as an internal standard using $\mathrm{CDCl}_{3}$ as solvent and the LC-MS spectra have been carried out with Waters Micromass Q-Tof Micro instrument. The elemental analyses were carried out with a Thermo Finnigan elemental analyzer. The X-band ESR spectra of

*Corresponding author: Bendre RS, School of Chemical Sciences, North Maharashtra University, Maharashtra, India, Tel: 9422211435; E-mail: bendrers@gmail.com

Received December 11, 2016; Accepted December 30, 2016; Published January 02, 2017

Citation: Samina KT, Jamatsingh DR, Suresh DR, Jaiprakash NS, Amar AH, et al. (2017) Crystal Structure, Spectral Characterization and Biologically Studies of Mononuclear Transition Metal Complexes Derived from New $\mathrm{N}_{2} \mathrm{O}_{2}$ Type Ligand. Mod Chem Appl 5: 211. doi: 10.4172/2329-6798.1000211

Copyright: (c) 2017 Samina KT, et al. This is an open-access article distributed under the terms of the Creative Commons Attribution License, which permits unrestricted use, distribution, and reproduction in any medium, provided the original author and source are credited. 
Citation: Samina KT, Jamatsingh DR, Suresh DR, Jaiprakash NS, Amar AH, et al. (2017) Crystal Structure, Spectral Characterization and Biologically Studies of Mononuclear Transition Metal Complexes Derived from New $\mathrm{N}_{2} \mathrm{O}_{2}$ Type Ligand. Mod Chem Appl 5: 211. doi: 10.4172/23296798.1000211

Page 2 of 7

copper complex are recorded on a JES-FA200 EPR spectrometer with DPPH as standard. Magnetic susceptibilities are measured at room temperature on a guoy balance using $\mathrm{Hg}\left[\mathrm{Co}(\mathrm{NCS})_{4}\right]$ as reference. SEMEDS analyses were performed on SEM JEOL JSM 6360 and JEOL JSM 5400, Japan. Molar conductance of metal complexes was calculated in DMF at room temperature on Systronic Conductivity Bridge.

\section{Synthesis of Schiff base $(\mathrm{L})$}

The ligand was prepared by dropwise addition of a warm ethanolic solution of o-phenylenediamine $(1 \mathrm{mmol})$ to constantly stirring warm solution of 2-hydroxy-6-isopropyl-3-methyl benzaldehyde (2 mmol) in ethanol. The resulting solution was refluxed for $3 \mathrm{~h}$, formation of orange precipitate. The obtained product was filtered, washed with cold ethanol and recrystallized from ethanol and dried at room temperature. Yield: 77 \%Colour: Orange. Anal. calcd for $\mathrm{C}_{28} \mathrm{H}_{32} \mathrm{~N}_{2} \mathrm{O}_{2}(\%)$ : C 78.47, $\mathrm{H}$ 7.53, N 6.54; Found: C 78.31, H 8.16 N 6.61. FT-IR ( $\mathrm{KBr}$ pellet, $\left.\mathrm{cm}^{-1}\right)$ $v_{\max }: 3412(\mathrm{OH}), 1601(\mathrm{C}=\mathrm{N}), 1460(\mathrm{C}=\mathrm{C}), 1253(\mathrm{C}-\mathrm{O})$. UV-vis (DMF) $\lambda_{\max }^{\max }(\mathrm{nm}): 268,341 .{ }^{1} \mathrm{H}-\mathrm{NMR}\left(\mathrm{CDCl}_{3}, 400 \mathrm{MHz}\right)(\delta, \mathrm{ppm}): 14.16(\mathrm{~s}$, $2 \mathrm{H},-\mathrm{OH}), 7.39-7.37$ (m, 2H, Ar), 7.32-7.30 (m, 2H, Ar), $7.20(\mathrm{~d}, 2 \mathrm{H}$, $\mathrm{J}=8 \mathrm{~Hz}), 6.74(\mathrm{~d}, 2 \mathrm{H}, \mathrm{Ar}), 3.48-3.45\left(\mathrm{~m}, 2 \mathrm{H},-2\left(\mathrm{CH}_{3}\right)\right), 2.17(\mathrm{~s}, 6 \mathrm{H}$, $\left.2\left(\mathrm{CH}_{3}\right)\right), 1.19-1.24\left(\mathrm{~m}, 12 \mathrm{H}, 4\left(\mathrm{CH}_{3}\right)\right) .{ }^{13} \mathrm{C}-\mathrm{NMR}\left(\mathrm{CDCl}_{3}, 400 \mathrm{MHz}\right)(\delta$, ppm): $162.31,160.88,147.99,142.74,134.72,127.34,124.05,121.16$, 114.95, 28.09, 24.07, 15.60. MS (m/z): calcd 428.57; obsv 429.4 .

\section{General procedure for the synthesis of mononuclear metal complexes}

The complexes were prepared by dropwise addition of $(1 \mathrm{mmol})$ warm ethanolic solution of ligand to the corresponding suitable ethanolic metal acetate or chloride salts $(2 \mathrm{mmol})$ in basic condition under inert atmosphere nitrogen gas. The reaction mixture was refluxed till completion of reaction, the precipitate was obtained and collected product was washed with cold ethanol and then diethyl ether.

Mononuclear $\mathrm{Mn}(\mathrm{III})$ complex [1]: Yield: $71 \%$. Colour: reddish brown. Anal. calcd for $\mathrm{C}_{30} \mathrm{H}_{33} \mathrm{MnN}_{2} \mathrm{O}_{4}(\%)$ : C 66.66, H 6.15, N, 5.18; Found: C 64.93, H 5.91, N 5.97. FT-IR (KBr, pellet $\left.\mathrm{cm}^{-1}\right) v_{\text {max }}: 1591$ $(\mathrm{C}=\mathrm{N}), 1276(\mathrm{C}-\mathrm{O}), 1382(\mathrm{C}=\mathrm{C}), 530(\mathrm{M}-\mathrm{O}), 480(\mathrm{M}-\mathrm{N})$. UV-Vis (DMF) $\lambda_{\text {max }}(\mathrm{nm}): 268,342,471$. LC-MS (m/z): calcd 540.53; obsv 481.3. $\mu_{\text {eff }}$ 4.82 B.M. Conductance $\left(\Lambda_{\mathrm{M}}, \Omega^{-1} \mathrm{~cm}^{2} \mathrm{~mol}^{-1}\right)$ in DMF: 9.60 .

Mononuclear Co(II) complex [2]: Yield: 65\%. Colour: brown. Anal. calcd for $\mathrm{C}_{28} \mathrm{H}_{30} \mathrm{CoN}_{2} \mathrm{O}_{2}$ (\%): $\mathrm{C} 69.27 \mathrm{H} \mathrm{6.23,} \mathrm{N} \mathrm{5.77;} \mathrm{Found:} \mathrm{C}$ 68.29, H 5.14, N 5.58. FT-IR (KBr pellet, $\left.\mathrm{cm}^{-1}\right) v_{\max }: 1541(\mathrm{C}=\mathrm{N}), 1205$ (C-O), $1382(\mathrm{C}=\mathrm{C}), 530(\mathrm{M}-\mathrm{O}), 480(\mathrm{M}-\mathrm{N})$. UV-Vis $(\mathrm{DMF}) \lambda_{\max }(\mathrm{nm})$ : 264, 506, 620. LC-MS (m/z): calcd 485.48; obsv $485.3 \mu_{\text {eff: }}$ : 3.80 B.M. Conductance $\left(\Lambda_{\mathrm{M}}, \Omega^{-1} \mathrm{~cm}^{2} \mathrm{~mol}^{-1}\right)$ in DMF: 14.35 .

Mononuclear $\mathrm{Ni}(\mathrm{II})$ complex [3]: Yield: $80 \%$. Colour: reddish orange. Anal. calcd for $\mathrm{C}_{28} \mathrm{H}_{30} \mathrm{~N}_{2} \mathrm{NiO}_{2}$ (\%): C 69.31, H 6.23, N 5.77; Found: C 70.34, H 6.03, N 6.35. FT-IR ( $\mathrm{KBr}$ pellet, $\left.\mathrm{cm}^{-1}\right) v_{\max }: 1560$ $(\mathrm{C}=\mathrm{N}), 1234(\mathrm{C}-\mathrm{O}), 1452(\mathrm{C}=\mathrm{C}), 474(\mathrm{M}-\mathrm{O}), 432(\mathrm{M}-\mathrm{N})$. UV-Vis (DMF) $\lambda_{\max }$ (nm): 267, 307, 386, 490, 547. LC-MS (m/z): calcd 485.23; obsv 485.41. Conductance $\left(\Lambda_{\mathrm{M}}, \Omega^{-1} \mathrm{~cm}^{2} \mathrm{~mol}^{-1}\right)$ in DMF: 15.64 .

Mononuclear $\mathrm{Cu}(\mathrm{II})$ complex [4]: Yield: 78\%. Colour: Shining dark green. Anal. calcd for $\mathrm{C}_{28} \mathrm{H}_{30} \mathrm{CuN}_{2} \mathrm{O}_{2}$ (\%): C 68.62, $\mathrm{H}$ 6.17, $\mathrm{N}$ 5.72, Found: C 66.79, H 5.18, N 5.67. FT-IR (KBr, cm-1) $v_{\text {max }}: 1600(\mathrm{C}=\mathrm{N})$, 1240 (C-O), 1404 (C=C), 550 (M-O), 455 (M-N). UV-Vis: (DMF) $\lambda_{\max }$ (nm): 264, 444, 632. LC-MS (m/z): calcd 490.10; obsv 490.40. $\mu_{\text {eff }}: 1.75$ B.M. Conductance $\left(\Lambda_{\mathrm{M}} \Omega^{-1} \mathrm{~cm}^{2} \mathrm{~mol}^{-1}\right): 12.67 . \mathrm{g}_{\mathrm{I}}=2.2317, \mathrm{~g}=2.0472$.

\section{Bioassay}

Protocol for antibacterial activity: The antibacterial activity of the compounds was performed by enumerating the viable number of cells upon in the nutrient broth containing various concentrations of compounds. The viable number is represented by colony count method. The test organisms used on which the antibacterial activity was performed were Escherichia Coli, Bacillus subtilis (NCIM-2063), Pseudomonas aeruginosa (NCIM-2036) and Staphylococcus aureus (NCIM-2901). The minimum inhibitory concentration (MIC $\mu \mathrm{g} /$ $\mathrm{mL}$ ) values were determined. The lowest MIC values show the potent activity. Ciprofloxacin and Ampicillin were used as standard drugs. All the experiment were carried out in triplicate and the averaged results are considered [14].

Protocol for antifungal activity: The antifungal activity was evaluated against different fungal strains, such as Candida albicans (NCIM 3471), Fusarium oxysporum (NCIM1332), Aspergillus flavus (NCIM 539), Aspergillus niger (NCIM 1196), and Cryptococcus neoformans (NCIM 576). Minimum inhibitory concentration (MIC, $\mu \mathrm{g} / \mathrm{mL}$ ) values of all the compounds were determined using the standard agar dilution method as per CLSI guidelines. By using miconazole and fluconazole as standard antifungal drugs. All the experiments are performed in triplicate and average results are considered [15].

Protocol for antioxidant activity: DPPH (2,2-diphenyl-1picrylhydrazyl) radical scavenging activity was evaluated according to the reported method [16,17]. Ascorbic acid was used as standard. Each sample and positive control (ascorbic acid) were performed in triplicate. Scavenging activity versus concentration in ppm were plotted to estimate a $50 \%$ reduction of its initial value $\left(\mathrm{EC}_{50}\right)$. Lower absorbance of the reaction mixture indicates higher free radical scavenging activity. The capability to scavenge the DPPH radical was calculated using the following equation:

DPPH radical scavenging activity $(\%)=$ Absorbance $_{(\text {control) }}-$ Absorbance $_{\text {(standard) }} /$ Absorbance $_{\text {(control) }} \times 100$

Where, Absorbance ${ }_{(\text {control) }}$ :Absorbance of DPPH radical+methanol Absorbance $_{\text {(standard) }}:$ Absorbance of DPPH radical+extract/standard.

\section{Results and Discussion}

The symmetrical Schiff base was prepared by simply condensation of 2-hydroxy-3-methyl-benzaldehyde [18] with o-phenylenediamine in 2:1 molar ratio in ethanolic solution (Figure 1). The $\mathrm{Mn}(\mathrm{III}$ ),

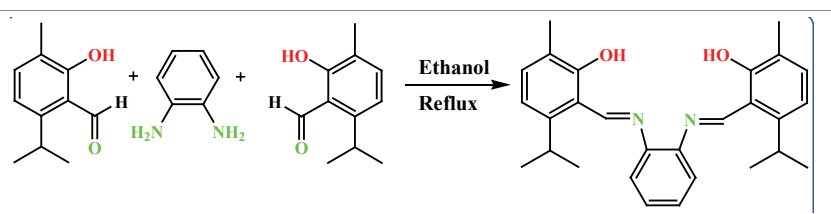

Figure 1: SynthesisofLigandHL6,6'-((1E,1'E)-(1,2-phenylenebis(azanylylidene)) bis(methanylylidene))bis(5-isopropyl-2-methylphenol).

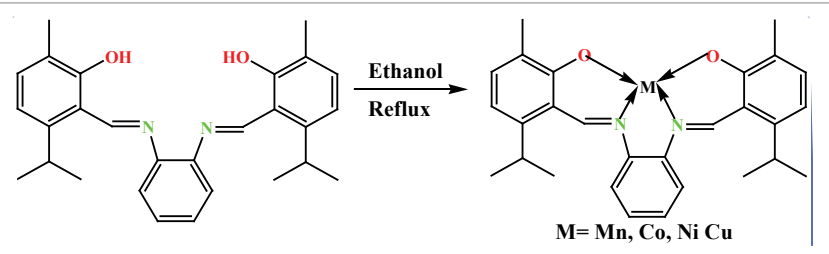

Figure 2: Synthesis of mononuclear metal (II) complexes with 6,6'-((1E,1'E)(1,2-phenylenebis(azanylylidene))bis(methanylylidene))bis(5-isopropyl-2methylphenol). 
Citation: Samina KT, Jamatsingh DR, Suresh DR, Jaiprakash NS, Amar AH, et al. (2017) Crystal Structure, Spectral Characterization and Biologically Studies of Mononuclear Transition Metal Complexes Derived from New $\mathrm{N}_{2} \mathrm{O}_{2}$ Type Ligand. Mod Chem Appl 5: 211. doi: 10.4172/23296798.1000211

Page 3 of 7

\begin{tabular}{|c|c|c|c|c|}
\hline Compounds Name & $\begin{array}{c}\text { E. coli } \\
\text { (MIC } \mu \mathrm{g} / \mathrm{mL})\end{array}$ & $\begin{array}{l}\text { P. aeruginosa } \\
\text { (MIC } \mu \mathrm{g} / \mathrm{mL} \text { ) }\end{array}$ & $\begin{array}{l}\text { B. subtilis } \\
\text { (MIC } \mu \mathrm{g} / \mathrm{mL} \text { ) }\end{array}$ & $\begin{array}{l}\text { S. aureus } \\
\text { (MIC } \mathrm{g} / \mathrm{mL} \text { ) }\end{array}$ \\
\hline Carvacrol & 72 & 97 & 56 & 129 \\
\hline Carvcrol aldehyde & 95 & 120 & 75 & 193 \\
\hline Ligand & 102 & 49 & 63 & 77 \\
\hline $\mathrm{Mn}(\mathrm{II})$ & 111 & 101 & 81 & 115 \\
\hline $\mathrm{Co}(\mathrm{II})$ & 168 & 170 & 230 & 99 \\
\hline $\mathrm{Ni}(\mathrm{II})$ & 63 & 93 & 74 & 56 \\
\hline $\mathrm{Cu}(\mathrm{II})$ & 74 & 85 & 102 & 74 \\
\hline Ciprofloxacin & 25 & 25 & 50 & 50 \\
\hline Ampicillin & 100 & 100 & 250 & 250 \\
\hline
\end{tabular}

Table 1: The antibacterial activity representation.

\begin{tabular}{|c|c|c|c|c|}
\hline Compounds Name & $\begin{array}{l}\text { C. albicans } \\
\text { (MIC } \mu \mathrm{g} / \mathrm{mL} \text { ) }\end{array}$ & $\begin{array}{c}\text { A. flavus } \\
\text { (MIC } \mu \mathrm{g} / \mathrm{mL} \text { ) }\end{array}$ & $\begin{array}{c}\text { A. niger } \\
\text { (MIC } \mu \mathrm{g} / \mathrm{mL} \text { ) }\end{array}$ & $\begin{array}{l}\text { C. neoformans } \\
\text { (MIC } \mu \mathrm{g} / \mathrm{mL} \text { ) }\end{array}$ \\
\hline Carvacrol & 125 & 125 & 125 & 100 \\
\hline Carvacrol aldehyde & * & 125 & * & 225 \\
\hline Ligand & 100 & 150 & 150 & * \\
\hline $\mathrm{Mn}(\mathrm{II})$ & 125 & 225 & 125 & * \\
\hline $\mathrm{Co}(\mathrm{II})$ & 100 & 100 & * & 150 \\
\hline $\mathrm{Ni}(\mathrm{II})$ & 150 & * & 100 & 125 \\
\hline $\mathrm{Cu}(\mathrm{II})$ & 150 & * & * & * \\
\hline Miconazole & 25 & 12.5 & 25 & 25 \\
\hline Fluconazole & 12.5 & 6.25 & 12.5 & 6.25 \\
\hline
\end{tabular}

Table 2: The antifungal activity representation.

$\mathrm{Co}(\mathrm{II}), \mathrm{Ni}(\mathrm{II})$ and $\mathrm{Cu}(\mathrm{II})$ mononuclear complexes were synthesized by the direct reaction of ligand with an equimolar amount of metal(II) acetate/ chloride salts in ethanol in 1:1 molar ratio (Figure 2). All the compounds are soluble in polar solvents. The spectral analyses agree well with the proposed structure of the complexes. All the compounds were subjected to in vitro antibacterial, antifungal and antioxidant activities.

\section{Biological activity}

As per the literature survey carvacrol possess good antibacterial, antifungal and antioxidant activities [19]. Our antibacterial data illustrated in Table 1, that the antibacterial activity decreases upon formylation of carvacrol to carvacrol aldehyde as compared to the carvacrol. While schiff base ligand possesses the superior activity as compared to the carvacrol against Pseudomonas aeruginosa, Bacillius subtilis and Staphylococcus aureus. All the metal complexes presented better antibacterial activity against the Staphylococcus aureus as compared to carvacrol (Table 2). The $\mathrm{Ni}$ (II) and $\mathrm{Co}(\mathrm{II})$ complexes exhibited better antibacterial activity than the ligand against all the microbes and standard ampicillin. The antifungal activity results indicated that carvacrol aldehyde possesses good antifungal activity against the Aspergillus flavus and Cryptococcus neoformans. The schiff base ligand shows the better activity in contrast to carvacrol for the fungal strain Candida albicans and moderate to Aspergillus flavus and Aspergillus niger. All the complexes show good activity against the Candida albicans.. The $\mathrm{Co}(\mathrm{II})$ and $\mathrm{Ni}(\mathrm{II})$ complexes showed better activity against Candida albicans, Aspergillus flavus and Aspergillus niger, Cryptococcus neoformans respectively. The better antibacterial and antifungal activities of these complexes as compared to the ligand may be explained on the basis of chelation theory [20]. The process of scavenging DPPH-free radicals has been used to assess the antioxidant activity of specific compounds [21]. DPPH is a stable free radical that can accept an electron or hydrogen radical and get converted to a stable, diamagnetic molecule. DPPH has an odd electron and has strong absorption band at $517 \mathrm{~nm}$. When this electron becomes paired off, the absorption decreases stiochometrically with respect to the number of electrons or hydrogen atoms taken up. Such a change in the absorbance by this reaction has been extensively adopted to test the capacity of several molecules to act as free radical scavengers (Table 3 ). Hence, more rapidly the absorbance decreases, the more potent is the antioxidant activity of the compound [22]. Our result indicate that carvacrol aldehyde possesses the strong activity as compared to the carvacrol while the Schiff base ligand possess lesser activity as compared to both. However upon complexation with metal ions viz $\mathrm{Mn}(\mathrm{III})$ and $\mathrm{Cu}(\mathrm{II})$ the activity was improved significantly. All the compounds showed comparable or better activity to that of standard ascorbic acid. The $\mathrm{Mn}(\mathrm{III})$ and $\mathrm{Cu}(\mathrm{II})$ complex showed significantly higher antioxidant activity followed by $\mathrm{Ni}(\mathrm{II})$ and $\mathrm{Co}(\mathrm{II})$ complexes at different concentrations.

\section{$\mathrm{X}$-ray crystallographic analysis}

Yellow colored crystal of suitable size $0.23 \times 0.22 \times 0.21 \mathrm{~mm}^{3}$ and mounted on 'Bruker APEX-II CCD' diffractometer equipped with graphite monochromated Mo Ka radiation in the wavelength of $0.71073 \AA$ at room temperature. The summary of crystallographic parameters, data collection and refinement is given in Table 4 and the additional details concerning the data collections, structure solution and refinement are included in the supporting data. The CCDC No. for Ligand is 1443334 . The single crystal of the Schiff base demonstrated the monoclinic system having P2 space group with the two molecules in the unit cell. The ORTEP diagram with numbering and packing diagram are shown in the Figure 3 . The selected bond lengths and bond angles are depicted in Table 6 While, the hydrogen bonding parameters are given in Table 5. The crystal structure of the symmetric Schiff base ligand represented, the $\mathrm{N} 1-\mathrm{C} 15$ and $\mathrm{C}_{8}-\mathrm{N}_{2}$ distances as 1.286(8) and $1.277(8) \mathrm{A}^{\circ}$ respectively for $\mathrm{C}=\mathrm{N}$ double bonding. The two $\mathrm{C}_{4}-\mathrm{O}_{1}$ and $\mathrm{C}_{21}-\mathrm{O}_{2}$ having bond distances $1.339(8)$ and $1.349(8) \mathrm{A}^{\circ}$ respectively illustrated the $\mathrm{C}-\mathrm{O}$ phenolic single bond. The intramolecular hydrogen bonding formed by the $\mathrm{H}_{1}-\mathrm{O}_{1}-\mathrm{N}_{2}$ and $\mathrm{H}_{2}-\mathrm{O}_{2}-\mathrm{N}_{1}$, with distances of 2.617 and $2.579 \mathrm{~A}^{\circ}$ has resulted in the formation of a five membered 
Citation: Samina KT, Jamatsingh DR, Suresh DR, Jaiprakash NS, Amar AH, et al. (2017) Crystal Structure, Spectral Characterization and Biologically Studies of Mononuclear Transition Metal Complexes Derived from New $\mathrm{N}_{2} \mathrm{O}_{2}$ Type Ligand. Mod Chem Appl 5: 211. doi: 10.4172/23296798.1000211

Page 4 of 7

chelating ring. There is no solvent molecule appear in the structure. From this crystal structure study, it is confirmed that the symmetric Schiff base having two imine nitrogen atoms and two phenolic oxygen atoms $\left(\mathrm{N}_{1}, \mathrm{~N}_{2}, \mathrm{O}_{1}, \mathrm{O}_{2}\right)$ has been successfully synthesized and suggests that this ligand can easily act as tetradentate donor $[23,24]$.

\section{Spectral characterization}

FT-IR: The IR spectroscopy is used to determine the characteristic peaks $(\mathrm{OH}, \mathrm{C}=\mathrm{N}, \mathrm{C}-\mathrm{O})$ in ligand before and after complexation. The IR spectra of the ligand and complexes are compared, the band at 1601 $\mathrm{cm}^{-1}$ is characteristic of the azomethine nitrogen atom present in the schiff base ligand is found to shift to lower frequency region 1546$1556 \mathrm{~cm}^{-1}$ in all the complexes and illustrated the involvement of the azomethine nitrogen atom in coordination. The peak at $3412 \mathrm{~cm}^{-1}$ appear for the phenolic $-\mathrm{OH}$ group. The absence of the broad band at $3500-3100 \mathrm{~cm}^{-1}$. indicated the absence of coordinated water molecule to complexes. The C-O peak appearing in the ligand at $1298 \mathrm{~cm}^{-1}$ is shifted to $1340-1388 \mathrm{~cm}^{-1}$ in all complexes. The involvement of oxygen and nitrogen atoms in coordination with metal is further definited by the appearance of weak and low frequency bands in the range 400-600 $\mathrm{cm}^{-1}$ corresponding to the $\mathrm{M}-\mathrm{O}$ and $\mathrm{M}-\mathrm{N}$ respectively [25].

Electronic spectra: The absorption value of high energy 265-280 $\mathrm{nm}$ and $340-490 \mathrm{~nm}$ are assigned to the intraligand $\pi \rightarrow \pi^{*}$ and $\mathrm{n} \rightarrow \pi^{*}$ transitions respectively. The electronic spectra of copper consist of weak d-d transition in the visible region as a broad band at $632 \mathrm{~nm}$ attributed to square planar complexes of similar tetradentate schiff base ligands with o-phenylenedimaine, The nickel complex shows the absorption at $547 \mathrm{~nm}$ indicating that the complex is diamagnetic nature and possesses square planar geometry. The absorption at $506 \mathrm{~nm}$ and $620 \mathrm{~nm}$ shows cobalt complex possess the square planar geometry [26].

Mass: In the mass spectra of the ligands and complexes the molecular ion peak is significantly more abundant than other fragment ions. The proposed fragmentations are equivalent with the empirical formula of proposed structure of the ligands and complexes.

NMR: In the ${ }^{1} \mathrm{H}$ NMR spectrum of the ligand in DMSO shows the following signals: $4.16 \delta$ singlet are assigned to the phenolic $-\mathrm{OH}$ group and the values 7.39-7.37, 7.32-7.30, 7.20, $6.74 \delta$ are assigned to the aromatic region, the peak at multiplet 3.48-3.45 $\delta$ and 1.19-1.24 $\delta$ are attributed to the 2- $\mathrm{CH}$ and of four methyl group of isopropyl group respectively and singlet peak at $2.17 \delta$ assigned for methyl group.

SEM: Scanning electron micrograph (SEM) have been currently used to determine the morphology and the grain size of the metal complexes. The SEM photograph of the complexes are illustrated in the Figure 4 for all the metal complexes the SEM photograph were taken in the different scale range from $1 \mu \mathrm{m}$ to $50 \mu \mathrm{m}$. From the SEM photograph it was noted there is a uniform matrix in all the metal complexes. The photograph of $\mathrm{Mn}$ (II) complex shows the flakes like morphology while Co(II) complex exhibit the rod like morphology. The $\mathrm{Ni}(\mathrm{II})$ and $\mathrm{Cu}(\mathrm{II})$ displays the fibre like morphology.

Conductivity measurement: The molar conductivity values of the complexes were in the range $15-25 \Omega^{-1} \mathrm{~cm}^{-1} \mathrm{~mol}^{-1}$. This value indicated that the complexes having non-electrolytic in nature [27].

Magnetic susceptibility: The Mn(III) complex shows the distorted square planer geometry having magnetic moment 4.85 B.M. The magnetic moment of the $\mathrm{Co}$ (II) complexes exhibit at 2.81 BM [28] consistent with Square planar geometry $\mathrm{Ni}(\mathrm{II})$ complexes are square planar and diamagnetic in nature [29] while the magnetic moment of $\mathrm{Cu}$ (II) complex exhibited in the range 1.75 representing that copper has square planar geometry showing one unpaired electron [30,31].

ESR spectra: The ESR spectra of the CuL complex in DMF solution at $77 \mathrm{~K}$ at liquid nitrogen temperature exhibits in the perpendicular region, three of four hyperfine features are well resolved while the fourth one is overlapped by $g$ features [32]. The values of ESR parameters $G_{\text {avg' }}$, $\mathrm{G}, \alpha^{2}, f$ for $\mathrm{Cu}(\mathrm{II})$ complex calculated are $2.22,2.040,2.1,5.75,186 \times$ $10^{-4}, 0.79,118$, respectively. From the calculated values it illustrated that
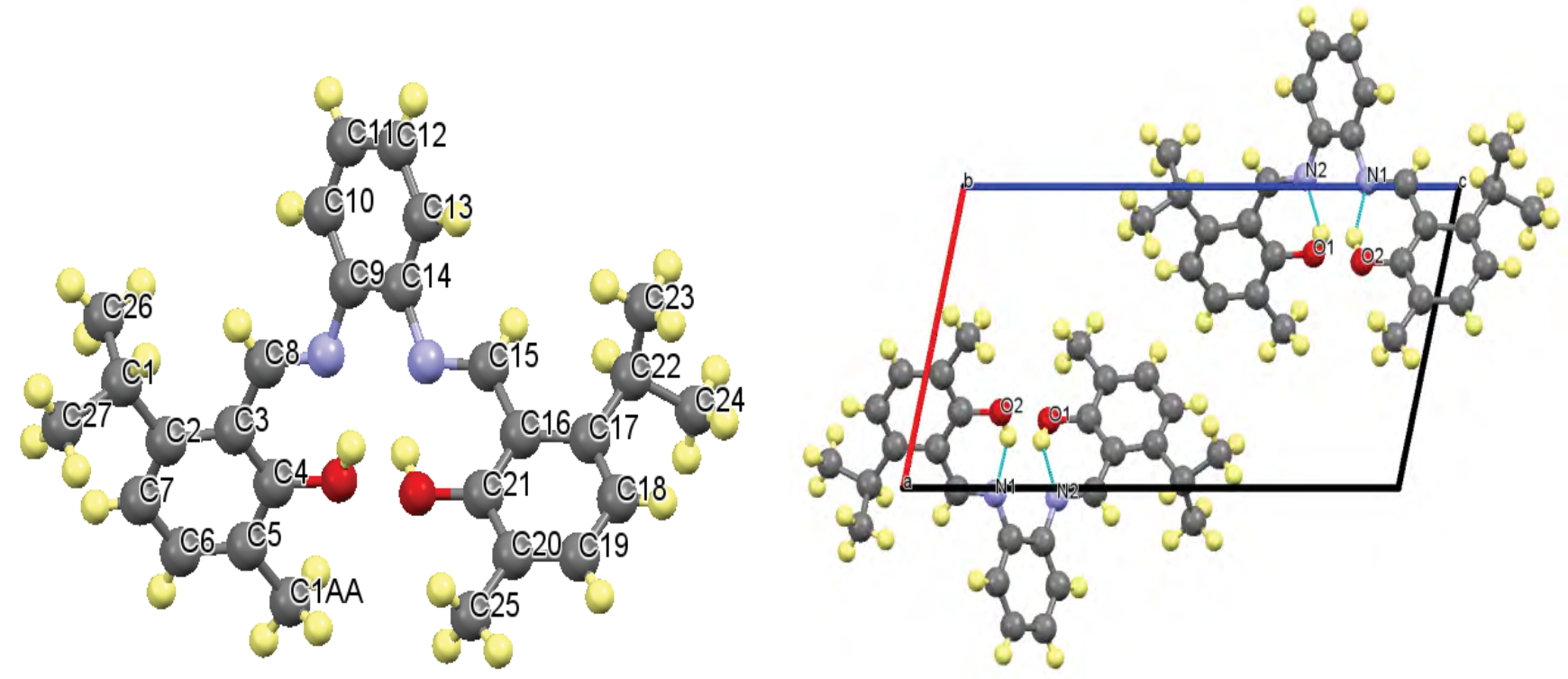

Figure 3: ORTEP diagram with atomic labeling and crystal packing diagram viewed along b with $\mathrm{O}-\mathrm{H}$-- $\mathrm{N}$ intramolecular hydrogen bond is shown as a light blue dashed line. 
Citation: Samina KT, Jamatsingh DR, Suresh DR, Jaiprakash NS, Amar AH, et al. (2017) Crystal Structure, Spectral Characterization and Biologically Studies of Mononuclear Transition Metal Complexes Derived from New $\mathrm{N}_{2} \mathrm{O}_{2}$ Type Ligand. Mod Chem Appl 5: 211. doi: 10.4172/23296798.1000211
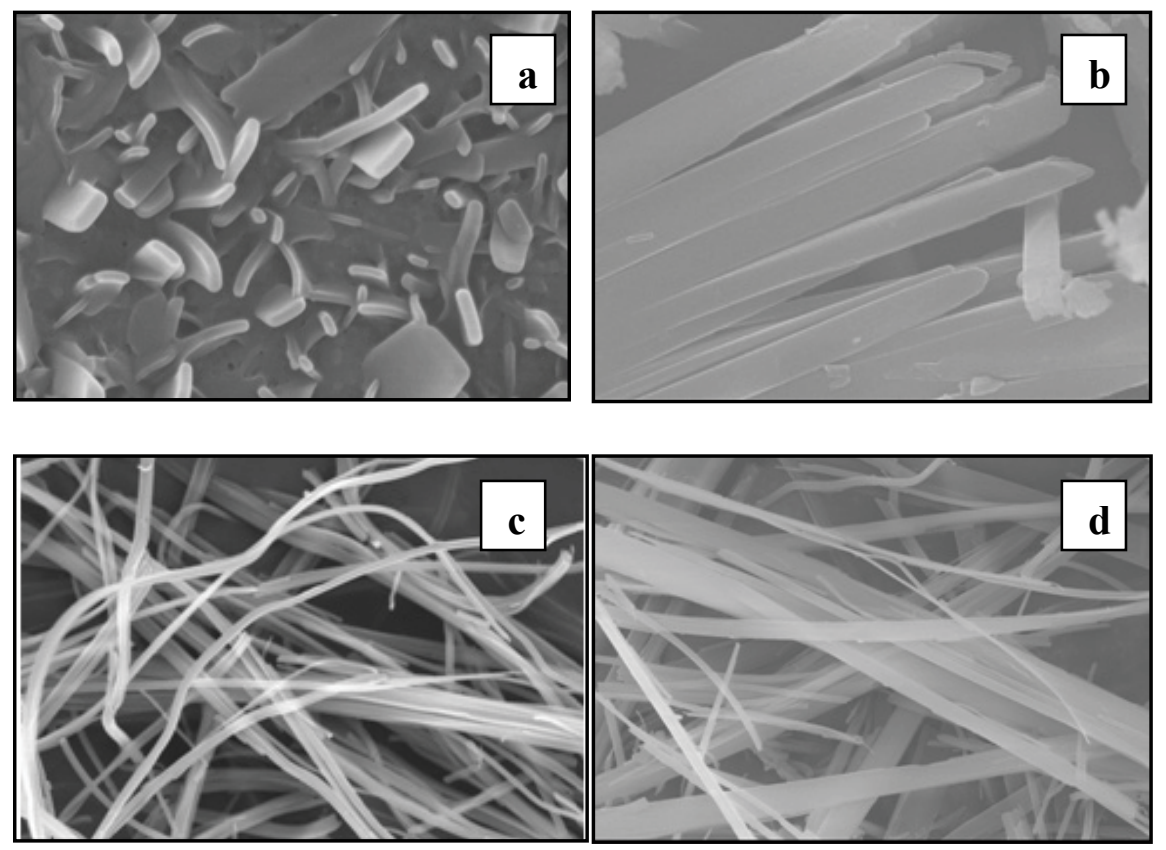

$\mathrm{a}=\mathrm{Mn}(\mathrm{III}), \mathrm{b}=\mathrm{Co}(\mathrm{II}), \mathrm{c}=\mathrm{Ni}(\mathrm{II}), \mathrm{d}=\mathrm{Cu}(\mathrm{II})$

Figure 4: SEM photograph of all the mononuclear complexes.

\begin{tabular}{|c|c|c|}
\hline & Compound Name & \\
\hline Carvacrol & 0.1137 \\
\hline Carvacrol aldehyde & 0.1107 \\
\hline Ligand & 0.1142 \\
\hline $\mathrm{Mn}(\mathrm{II})$ & 0.1124 \\
\hline $\mathrm{Co}(\mathrm{II})$ & 0.1172 \\
\hline $\mathrm{Ni}(\mathrm{II})$ & 0.1158 \\
\hline $\mathrm{Cu}(\mathrm{II})$ & 0.1135 \\
\hline Ascorbic acid & 0.1203 \\
\hline
\end{tabular}

Table 3: The antioxidant activity representation.

\begin{tabular}{|c|c|}
\hline Empirical formula & $\mathrm{C}_{28} \mathrm{H}_{32} \mathrm{~N}_{2} \mathrm{O}_{2}$ \\
\hline Formula weight & 428.55 \\
\hline Temperature/K & 296.15 \\
\hline Crystal system & monoclinic \\
\hline Space group & $\mathrm{P} 2_{1}$ \\
\hline $\mathbf{a} / \AA$ & $8.561(2)$ \\
\hline $\mathbf{b} / \mathbf{A}$ & $8.705(2)$ \\
\hline c/Å & $16.556(4)$ \\
\hline$\alpha /^{\circ}$ & 90 \\
\hline$\beta /^{\circ}$ & 103.736(11) \\
\hline $\mathrm{y} /{ }^{\circ}$ & 90 \\
\hline Volume $/ \AA^{3}$ & 1198.6(5) \\
\hline $\mathbf{Z}$ & 2 \\
\hline$\rho_{\text {calc }} \mathbf{g} / \mathbf{c m}^{3}$ & 1.187 \\
\hline$\mu / \mathbf{m m}^{-1}$ & 0.074 \\
\hline$F(000)$ & 460.0 \\
\hline Crystal size $/ \mathrm{mm}^{3}$ & $0.23 \times 0.22 \times 0.21$ \\
\hline Radiation & MoKa $(\lambda=0.71073)$ \\
\hline $2 \Theta$ range for data collection $/^{\circ}$ & 2.532 to 50 \\
\hline Index ranges & $-10 \leq h \leq 10,-10 \leq k \leq 10,-19 \leq \mathrm{I} \leq 19$ \\
\hline Reflections collected & 16503 \\
\hline Independent reflections & $4178\left[R_{\text {int }}=0.0816, R_{\text {sigma }}=0.0720\right]$ \\
\hline
\end{tabular}


Citation: Samina KT, Jamatsingh DR, Suresh DR, Jaiprakash NS, Amar AH, et al. (2017) Crystal Structure, Spectral Characterization and Biologically Studies of Mononuclear Transition Metal Complexes Derived from New $\mathrm{N}_{2} \mathrm{O}_{2}$ Type Ligand. Mod Chem Appl 5: 211. doi: 10.4172/23296798.1000211

Page 6 of 7

\begin{tabular}{|c|c|}
\hline Data/restraints/parameters & $4178 / 1 / 297$ \\
\hline Goodness-of-fit on $\mathbf{F}^{2}$ & 1.127 \\
\hline Final $\mathbf{R}$ indexes [I>=20 $(\mathbf{I})]$ & $\mathrm{R}_{1}=0.1051, w \mathrm{R}_{2}=0.2745$ \\
\hline Final $\mathbf{R}$ indexes [all data] & $\mathrm{R}_{1}=0.1275, w R_{2}=0.2945$ \\
\hline Largest diff. peak/hole $/ \mathbf{e} \mathbf{A}^{-3}$ & $0.92 /-0.29$ \\
\hline Flack parameter & $-1.2(10)$ \\
\hline
\end{tabular}

Table 4: Crystallographic parameters, data collection and refinement is given as follows.

\begin{tabular}{|c|c|c|c|}
\hline \multicolumn{3}{|c|}{ Bond Lengths } & \multicolumn{2}{c}{ Bond Angles } \\
\hline $\mathrm{C}_{8}-\mathrm{N}_{2}$ & $1.277(8)$ & $\mathrm{O}_{1}-\mathrm{C}_{4}-\mathrm{C}_{3}$ & $123.1(6)$ \\
\hline $\mathrm{N}_{1}-\mathrm{C}_{15}$ & $1.286(8)$ & $\mathrm{O}_{2}-\mathrm{C}_{21}-\mathrm{C}_{16}$ & $121.5(6)$ \\
\hline $\mathrm{N}_{2}-\mathrm{C}_{9}$ & $1.422(8)$ & $\mathrm{N}_{2}-\mathrm{C}_{8}-\mathrm{C}_{3}$ & 1 \\
\hline $\mathrm{N}_{1}-\mathrm{C}_{14}$ & $1.422(9)$ & $\mathrm{N}_{1}-\mathrm{C}_{15}-\mathrm{C}_{16}$ & $124.1(6)$ \\
\hline $\mathrm{O}_{1}-\mathrm{C}_{4}$ & $1.339(8)$ & $\mathrm{C}_{8}-\mathrm{N}_{2}-\mathrm{C}_{9}$ & $122.0(6)$ \\
\hline $\mathrm{C}_{21}-\mathrm{O}_{2}$ & $1.349(8)$ & $\mathrm{C}_{15}-\mathrm{N}_{1}-\mathrm{C}_{14}$ \\
\hline
\end{tabular}

Table 5: Selected bond lengths $/ \mathrm{A}^{\circ}$ and angles $/{ }^{\circ}$ for Ligand $\mathrm{HL}$.

\begin{tabular}{|c|c|c|c|}
\hline D-H...A & d(D-H) & d(H...A) & d(D...A) \\
\hline $\mathrm{O}_{2}-\mathrm{H}_{2} \ldots \mathrm{N}_{1}$ & 0.820 & 1.847 & 2.580 \\
\hline $\mathrm{C}_{27}-\mathrm{H}_{27} \mathrm{~B} \ldots \mathrm{O}_{1}$ & 0.960 & 2.895 & 3.819 \\
\hline $\mathrm{C}_{24}-\mathrm{H}_{24} \mathrm{~B} \ldots \mathrm{O}_{2}$ & 0.960 & 2.916 & 148.10 \\
\hline $\mathrm{C}_{12}-\mathrm{H}_{12} \ldots \mathrm{O}_{2}$ & 0.930 & 2.867 & 3.841 \\
\hline
\end{tabular}

Table 6: The intramolecular hydrogen bonds and angles.

the copper complex follows the trend and also provides information about the unpaired electron that it is localized in $\mathrm{d}_{\mathrm{x}}{ }^{2}{ }_{\mathrm{y}}{ }^{2}$ orbital having ${ }^{2} \mathrm{~B}_{1 \mathrm{~g}}$ as ground state which is consistent with the square planar geometry [33]. The extent of geometrical distortion is measured by the $f=g / A$ ratio [34]. It has been reported that complex falls between 105-135 $\mathrm{cm}^{-1}$ and also ratio for tetragonally distorted complex falls in the range $135-250 \mathrm{~cm}^{-1}$ [35]. The current complex has $f=118 \mathrm{~cm}^{-1}$ indicating that copper complex has square planar geometry. The value of the exchange coupling interaction between two $\mathrm{Cu}(\mathrm{II})$ ions in terms of $\mathrm{G}$ has been explained by the Hathway expression $(0023) /(0023)$. From the expression, if $\mathrm{G}>4 \cdot 0$, the exchange interaction is negligible while when the value of $G<4.0$ significant exchange coupling is present in the solid complex [36]. This result indicates that the exchange coupling effects are not effective in the present complex. The value of in plane sigma bonding parameter $\alpha^{2}$ was expected from following expression,

$$
a^{2}=-\left(A_{1} / 0.036\right)+\left(g_{1}-2.0023\right)+3 / 7\left(g_{\perp}-2.0023\right)+0.04
$$

The value of $\alpha^{2}=0.5$, indicates complete covalent bonding, while the value of $\alpha^{2}=1.0$ suggests complete ionic bonding. The observed value of $a^{2}$ is less than 1 , which indicated that the complex has some covalent character in the ligand environment [37].

\section{Conclusion}

In this investigation we are reporting the synthesis and characterization of symmetrical salen based ligand and their $\mathrm{Mn}(\mathrm{III})$, $\mathrm{Co}(\mathrm{II}), \mathrm{Ni}(\mathrm{II})$ and $\mathrm{Cu}(\mathrm{II})$ complexes. The single crystal structure of Schiff base ligand have been solved by single x-ray crystallography which having two imine nitrogen atoms and two phenolic oxygen atoms act as tetradentate donor. The Schiff base ligand and metal complexes were screened for their biological activities such as, in vitro antibacterial, antifungal and antioxidant activities. The results indicated $\mathrm{Ni}(\mathrm{II})$ and $\mathrm{Cu}(\mathrm{II})$ complexes exhibit better antibacterial activity against Escherichia coli, Pseudomonas aeruginosa, Bacillus subtilis and Staphylococcus aureus as compared to carvacrol and standard drug (ciprofloxacin). The $\mathrm{Co}$ (II) complex show the good antifungal activity against Candida albicans, Aspergillus flavus, Cryptococcus neoformans as campared to parent molecule (carvacrol). The $\mathrm{Mn}$ (III) and $\mathrm{Cu}(\mathrm{II})$ complex shows the good antioxidant activity as comparable to standard drug (ascorbic acid).

\section{Acknowledgements}

Samina K Tadavi gratefully thanks UGC, New Delhi for Rajiv Gandhi National Fellowship for ST candidates. We are also thankful to Prof. TN Guru Row, IISC Bangalore for extending help in solving crystal structure of schiff base ligand.

\section{References}

1. Cozzi PG (2004) Metal-Salen Schiff base complexes in catalysis practical aspects. Chemical Society Reviews 337: 410-421.

2. Budige G, Puchakayala MR, Kongara SR, Hu A (2011) Synthesis characterization, and biological evaluation of mononuclear Co (II), Ni (II), Cu (II) and Pd (II) complexes with new N2O2 Schiff base ligands. Chemical and Pharmaceutical Bulletin 59: 166-171.

3. Yimer AM (2014) Chemical preparation, spectro-magnetic and biocidal studies on some divalent transition metal complexes of schiff's base derived from 1-Phenyl-2-(Pyridin-2-yl) ethane-1, 2-dione and ethylenediamine. Modern Chemistry \& Applications 2: 1-3.

4. Akila E, Usharani M, Rajavel R (2013) Metal (II) complexes of bioinorganic and medicinal relevance: Antibacterial, Antioxidant and DNA cleavage studies of tetradentate complexes involving $\mathrm{O}, \mathrm{N}$-donor environment of 3 3'-dihydroxybenzidine-based Schiff bases. International Journal of Pharmacy and Pharmaceutical Sciences 5: 573-581.

5. Djebbar SS, Benali BO, Deloume JP (1998) Synthesis characterization electrochemical behaviour and catalytic activity of manganese (II) complexes with linear and tripodal tetradentate ligands derived from Schiff bases. Transition Metal Chemistry 23: 443-447.

6. Klement R, Stock F, Elias H, Paulus H (1999) Copper (II) complexes with derivatives of salen and tetrahydrosalen a spectroscopic, electro chemical and structural study. Polyhedron 18: 3617-3628.

7. Niederhoffer EC, Timmons JH, Martell AE (1984) Thermodynamics of oxygen binding in natural and synthetic dioxygen complexes. Chemical Reviews 84: 137-203.

8. Martell AE, Sawyer DT (1988) Oxygen Complexes and Oxygen Activation by Transition Metals.

9. Holm RH (1987) Metal-centered oxygen atom transfer reactions. Chemical Reviews 87: 1401-1449.

10. Dixit PS, Srinivasan K (1988) The effect of clay-support on the catalytic epoxidation activity of a manganese (III)-Schiff base complex. Inorganic Chemistry $27:$ 4507-4509. 
Citation: Samina KT, Jamatsingh DR, Suresh DR, Jaiprakash NS, Amar AH, et al. (2017) Crystal Structure, Spectral Characterization and Biologically Studies of Mononuclear Transition Metal Complexes Derived from New $\mathrm{N}_{2} \mathrm{O}_{2}$ Type Ligand. Mod Chem Appl 5: 211. doi: 10.4172/23296798.1000211

11. Singh P, Goel RL, Singh BP (1975) Synthesis Characterization and Biological Activity of Schiff Bases. J Indian Chem Soc 52: 958-959.

12. Mohindru A, Fisher JM, Rabinovitz M (1983) Bathocuproine sulphonate a tissue culture-compatible indicator of copper-mediated toxicity. Nature 303: 64-65.

13. Raman N, Raja YP, Kulandaisamy A (2001) Synthesis and characterisation of $\mathrm{Cu}$ (II), Ni (II), Mn (II), Zn (II) and VO (II) Schiff base complexes derived fromo-phenylenediamine and acetoacetanilide. Journal of Chemical Sciences 113: 183-189.

14. Greenwood D, Slack RCB, Peutherer JF (1992) Medical Microbiology. 14 edn. ELBS London, UK.

15. Saundane AR, Rudresh K, Satyanarayan ND, Hiremath SR (1998) Pharmacological screening of $6 \mathrm{H}, 11 \mathrm{H}$-indolo $[3,2-\mathrm{c}]$ isoquinolin-5-ones and their derivatives. Indian Journal of Pharmaceutical Sciences 60: 379-383.

16. Chandrappa CP, Govindappa M, Kumar AN (2013) In vitro antimitotic, antiproliferative and DNA fragmentation assay of ethanol extract of Carmona retusa (Vahl.) Masam. Applied Cell Biology 2: 52-57.

17. Dery R, Davison R, Befus A (2001) International Archives of Allergy and Immunology 124: 201-204.

18. Rajput JD, Bagul SD, Tadavi SK, Karandikar PS (2016) Design, Synthesis, and Biological Evaluation of Novel Class Diindolyl Methanes (DIMs) Derived from Naturally Occurring Phenolic Monoterpenoids. Medicinal Chemistry 6: 123-128.

19. Kumar D, Rawat DS (2013) Synthesis and antioxidant activity of thymol and carvacrol based Schiff bases. Bioorganic and Medicinal Chemistry Letters 23 : 641-645

20. Mohie EM, Shishtawy RM (2013) Synthesis and Antimicrobial Activity of Aluminium (III), Nickel (II) and Zinc (II) Schiff base Complexes Derived from o-Phenylenediamine and Salicylaldehyde. Asian Journal of Chemistry 25: 2719-2721.

21. Bilgicli AT, Tekin Y, Alici EH, Yaraşir MN (2015) a-or $\beta$-Substituted functiona phthalocyanines bearing thiophen-3-ylmethanol substituents: synthesis, characterization, aggregation behavior and antioxidant activity. Journal of Coordination Chemistry 68: 4102-4116.

22. Harinath Y, Reddy DHK, Kumar BN, Apparao C (2013) Synthesis, spectral characterization and antioxidant activity studies of a bidentate Schiff base, 5-methyl thiophene-2-carboxaldehyde-carbohydrazone and its $\mathrm{Cd}$ (II), Cu (II), Ni (II) and Zn (II) complexes. Spectrochimica Acta Part A: Molecular and Biomolecular Spectroscopy 101: 264-272.

23. Rodríguez DMJ, Fernández MI, González NAM, Maneiro M (2006) Novel Manganese (III) Complexes with the Schiff Base N, N' - (1, 2-Phenylene) -bis (3-Hydroxysalicylidenimine). Synthesis and Reactivity in Inorganic, MetalOrganic and Nano-Metal Chemistry 36: 655-662.

24. Mota VZ, Carvalho GS, Corbi PP, Bergamini FR (2012) Crystal structure and theoretical studies of the keto-enol isomerism of N, N'-bis (salicylidene)o-phenylenediamine (salophen). Spectrochimica Acta Part A: Molecular and Biomolecular Spectroscopy 99: 110-115.
25. Kavitha P, Reddy KL (2016) Synthesis spectral characterisation morphology biological activity and DNA cleavage studies of metal complexes with chromone Schiff base. Arabian Journal of Chemistry 9: 596-605.

26. Lashanizadegan M, Boghaei DM, Shivapour Z, Seraj S (2010) Synthesis and Crystal Structure of Non-symmetric Tetradentate Complexes of Ni (II), Cu (II) Co (II), and Zn (II). Synthesis and Reactivity in Inorganic, Metal-Organic and Nano-Metal Chemistry 40: 373-377.

27. Youssef NS, Zahany EA, Barsoum BN, Seidy AM (2009) Synthesis and characterization of copper (II), cobalt (II), nickel (II), and iron (III) complexes with two diamine Schiff bases and catalytic reactivity of a chiral diamine cobalt (II) complex. Transition metal chemistry 34: 905-914

28. Dutta RL, Syamal A (1992) Elements of Magnetochemistry. 2nd edn. Elsevier.

29. Ray A, Banerjee S, Rosair GM, Gramlich V (2008) Variation in coordinative property of two different $\mathrm{N} 2 \mathrm{O} 2$ donor Schiff base ligands with nickel (II) and cobalt (III) ions: characterisation and single crystal structure elucidation. Structural Chemistry 19: 459-465.

30. Rabindra RP, Shilpa A (2011) Synthesis Characterization, and DNA-Binding and-Cleavage Properties of Dinuclear Cull Salophen/Salen Complexes. Chemistry and Biodiversity 8: 1245-1265.

31. Mohamed GG, Omar MM, Hindy AM (2005) Synthesis, characterization, and biological activity of some transition metals with Schiff base derived from 2-thiophene carboxaldehyde and aminobenzoic acid. Spectrochimica Acta Part A: Molecular and Biomolecular Spectroscopy 62: 1140-1150.

32. Klement R, Stock F, Elias H, Paulus H (1999) Copper (II) complexes with derivatives of salen and tetrahydrosalen: a spectroscopic, electrochemical and structural study. Polyhedron 18: 3617-3628.

33. Raj BB, Kurup MP, Suresh E (2008) Synthesis, spectral characterization and crystal structure of $\mathrm{N}$-2-hydroxy-4-methoxybenzaldehyde-N'-4-nitrobenzoyl hydrazone and its square planar $\mathrm{Cu}$ (II) complex. Spectrochimica Acta Part A Molecular and Biomolecular Spectroscopy 71: 1253-1260.

34. Boraey HA, Emam SM, Tolan DA, Nahas AM (2011) Structural studies and anticancer activity of a novel ( $\mathrm{N} 6 \mathrm{O} 4)$ macrocyclic ligand and its $\mathrm{Cu}$ (II) complexes. Spectrochimica Acta Part A: Molecular and Biomolecular Spectroscopy 78: 360-370.

35. Tabl AS, Saied FA, Hakimi AN (2008) Spectroscopic characterization and biological activity of metal complexes with an ONO trifunctionalized hydrazone ligand. Journal of Coordination Chemistry 61: 2380-2401.

36. Hathaway B, Billing DE (1970) The electronic properties and stereochemistry of mono-nuclear complexes of the copper (II) ion. Coordination Chemistry Reviews 5: 143-207.

37. Raman N, Ravichandran S (2005) Synthesis and Characterization of a New Schiff Base and its Metal Complexes Derived from the Mannich Base, N-(1piperidinobenzyl) acetamide. Synthesis and Reactivity in Inorganic, MetalOrganic, and Nano-Metal Chemistry 35: 439-444. 